\title{
Global Transport Challenges in Reducing Harmful Emissions: Selected Examples for Polish Part of Trans-European Road Network (TERN)
}

\author{
Mateusz BEDNARSKI ${ }^{\mathrm{a}, 1}$, Maciej GIS ${ }^{\mathrm{b}}$ and Marcin K. WOJS \\ ${ }^{\mathrm{a}}$ Warsaw University of Technology \\ ${ }^{\mathrm{b}}$ Motor Transport Institute
}

\begin{abstract}
Environmental pollution is a significant problem for the whole world. The lack of response from states can lead to many consequences. As consumption increases, so does the emission of harmful substances. According to the European Parliament, almost $30 \%$ of total $\mathrm{CO}_{2}$ (greenhouse gas affecting the greenhouse effect in the EU) comes from the transport sector, of which $72 \%$ is from road transport. Air pollution is a challenge for municipal authorities. According to the data, road transport accounted for approximately $5 \%$ of the creation of PM10 particles, ca. $7 \%$ of PM 2.5 and approximately $32 \%$ for $\mathrm{NO}_{\mathrm{x}}$. In Poland, suspended particles (PM10 and PM2.5) cause deaths of as many as 45,000 people a year. Therefore, it is necessary to undertake concrete efforts in order to reduce vehicle exhaust emissions as much as possible. Among them, solutions such as downsizing, hybridization of combustion engines or electrification are used. Based on the analyzes, the authors of the paper drew attention to the significant impact, in this process, of the modernization of energy infrastructure. Thanks to this, it is possible to simultaneously increase the share of zero-emission vehicles as well as the use of VtG (Vehicle to Grid) technology. What's more, the authors of the paper have determined for the main communication routes (TERN) in Poland, the potential for setting up refuelling stations for new types of vehicles, such as hydrogen or electric cars. Finally, the main risks have been presented for drivers, infrastructure and environment as a result of proposed changes.
\end{abstract}

Keywords. transport, Trans-European road network, electric cars, hydrogen, hybrid

\section{Introduction}

Air pollution is a challenge for municipal authorities. Increased emission of PM10 and PM2.5 particles is particularly noticeable in Poland in the autumn and winter period.

According to KOBIZE (The National Centre for Emission Management) data [1], in 2016 the main sources of PM10, PM2.5, and PAH (Polycyclic Aromatic Hydrocarbons) emissions were non-industrial combustion processes $(45 \%, 48 \%$ and $88 \%$ respectively of the total amount of emissions of such substances, estimated at

\footnotetext{
${ }^{1}$ Corresponding Author, Mail: mateusz.bednarski@pw.edu.pl.
} 
$259,156.3 \mathrm{Mg}, 145,506.9 \mathrm{Mg}$ and $146.3 \mathrm{Mg}$ ), the predominant share of which came from the combustion of solid fuels by households. In the case of nitric oxides $\left(\mathrm{NO}_{\mathrm{X}}\right)$, the industrial sector was the biggest source of emissions $(38 \%$ of the total amount of emissions of these substances, estimated at $726,431.2 \mathrm{Mg}$ ) but road transport was a second one (32\%). Lack of enough airflow causes the above dust and others to stay suspended above the city, as a result creating smog [2].

According to these data, road transport accounted for approximately 5\% of the creation of PM10 particles, ca. 7\% of PM2.5 and approximately $32 \%$ for $\mathrm{NO}_{\mathrm{X}}$. In Poland, suspended particles (PM10 and PM2.5) cause deaths of as many as 45,000 people a year. The issue of smog also affects other European cities. Therefore, it is necessary to undertake concrete efforts in order to reduce vehicle exhaust emissions as much as possible [3].

Therefore, it is necessary to diversify the fuels used and vehicle propulsion methods. Introducing green solutions is key to sustainable development and improving air quality in cities and more. Therefore, along with the introduction of transport electrification, actions in the energy sector are necessary.

\section{Energy Sector and green energy}

The demand for electricity is growing in Poland. According to the available information, in 2017 more than $170 \mathrm{TWh}$ of energy was produced in the country. It is $2.2 \%$ more than in 2016 . Table 1 presents the division of electricity production from various sources for the years $2016-2018$.

Table 1. Electricity production in Poland $[4,5]$

\begin{tabular}{lccc}
\hline \multicolumn{1}{c}{ Specification } & $\mathbf{2 0 1 6}$ & $\mathbf{2 0 1 7}$ & $\mathbf{2 0 1 8}$ \\
\cline { 2 - 4 } & & $\mathbf{G W h}$ & 170890 \\
\hline Total production & 166597 & 170335 & 150000 \\
\hline Thermal power stations & 140378 & 140259 & 49400 \\
\hline \multicolumn{1}{c}{ brown coal } & 51082 & 52281 & 83500 \\
\hline \multicolumn{1}{c}{ coal } & 80173 & 79265 & 12200 \\
\hline \multicolumn{1}{c}{ gas } & 5604 & 6161 & 4900 \\
\hline Hydromass/biogas & 3519 & 2552 & 2000 \\
\hline Wind power stations & 2335 & 2719 & 4800 \\
\hline Industrial power plants & 2981 & 3485 & 12200 \\
\hline $\begin{array}{l}\text { Independent power plants }- \text { renewable energy } \\
\text { installations }\end{array}$ & 11006 & 11417 & 3000 \\
\hline
\end{tabular}


The analysis shows that, compared to 2017 , electricity production from renewable energy sources (with the same installed capacity) dropped from 14.1 to 12.7 per cent. (21.6 TWh). Compared to 2017, in 2018 electric production from gas increased by $6039 \mathrm{GWh}$. Increases were also recorded in coal by $4235 \mathrm{GWh}$ and biomass by 2348 GWh. In turn, declines were noted, among others in the production of electricity from brown coal - minus $2847 \mathrm{GWh}$; from wind farms - minus $2061 \mathrm{GWh}$; from hydroelectric power plants - minus $719 \mathrm{GWh}$. The production of renewable energy from solar farms is growing.

Data from the International Renewable Energy Agency (IRENA) indicate that for most of the decade Poland has grown several times faster than the rest of Europe and the world in terms of renewable energy. Thanks to this, from 2009 to 2018 our share in European RES increased from 0.59 per cent. in 2009 up to 1.61 per cent in 2016, to reduce to 1.53 per cent in the past year (2018) (in the case of the world, our share increased from 0.15 to 0.35 per cent during this time). At that time, progress was significant. Installed capacity increased three and a half times from 1.75 to $8.23 \mathrm{GW}$, while Europe has not even managed to double its green energy production potential (increase by 81.3 per cent).

According to the "National Plan for Energy and Climate for 2021-2030" developed by the Ministry of Energy, a forecast has been made of the share of renewable energy in the national energy mix by 2030. As part of the EU-wide 2030 target, Poland declares that it will achieve by $203021 \%$ share of renewable energy in final gross energy consumption (total consumption in electricity, heating and cooling as well as for transport purposes), which depends on the competitiveness of these sources and their place and usefulness for the system.

In transport, a $10 \%$ share of renewable energy is expected to be achieved in 2020 and $14 \%$ by 2030 . By 2030 , an increase in the share of renewable energy sources is expected to reach about $27 \%$ in net electricity production. Pursuant to Directive 2009/28 / EC of the European Parliament and of the Council of 23 April 2009 on the promotion of the use of energy from renewable sources, Poland was obliged to achieve a minimum share of $15 \%$ of energy from renewable sources in gross final energy consumption by 2020. You can so assume that despite the decrease in the share of renewable energy sources in Poland, it will increase by 2030 and the assumed goals will be achieved.

\section{Charging stations for electric vehicles at the TERN transport routes - Proposal}

Based on TERN transport routes and traffic forecasts on national roads in 2020, developed by GDDKiA, it was possible to determine road sections of the largest and most significant importance. These roads include, among others national road no. 7 (Tricity-Warsaw-Cracow), A1 motorway (Tricity-Lodz), A2 motorway (WarsawFrankfurt/Oder), A4 motorway (Swiecko-Cracow), express road S8-A1 motorway national road 1 (Warsaw-Katowice) or national road 17 (Warsaw-Hrebenne).

On the above, it is proposed to deploy the fast-charging stations for electric vehicles. The distance between the charging points was calculated based on the average range of electric vehicles and the possibility of charging electric vehicles. The exact calculation of the distance between the charging stations is shown in Table 2 . 
Table 2. Calculating the distance between electric vehicle charging stations.

\begin{tabular}{lc}
\hline \multicolumn{1}{c}{ Condition } & Range \\
\hline The average range of electric vehicles when batteries are $100 \%$ charged & $175 \mathrm{~km}$ \\
\hline The average range of electric vehicles when batteries are $80 \%$ charged & $140 \mathrm{~km}$ \\
\hline Current reserve in $15 \%$ batteries & $26 \mathrm{~km}$ \\
\hline $5 \%$ safety factor & $\sim 9 \mathrm{~km}$ \\
\hline Distance between electric vehicle charging stations & $\sim 110 \mathrm{~km}$ \\
\hline
\end{tabular}

Based on the calculated distance between the charging points, it was possible to determine the minimum number of charging stations for electric vehicles on routes belonging to TERN.

The proposed application includes the construction of a quick charging station on the forecasted main transport routes in the country. Taking into consideration the assumptions regarding the distance between quick loading points and analyzing the possibility of their location, taking into account the current road infrastructure in the country (intersections, interchanges, road type), it was possible to determine the minimum number of charging points on individual routes. Calculating the distance between stations and the range of electric cars available on the European market has allowed the planning of the location of fast charging stations The following figure 1 presents a detailed proposal to build a quick charging station on specific road sections, being the forecasted main transport routes in Poland.

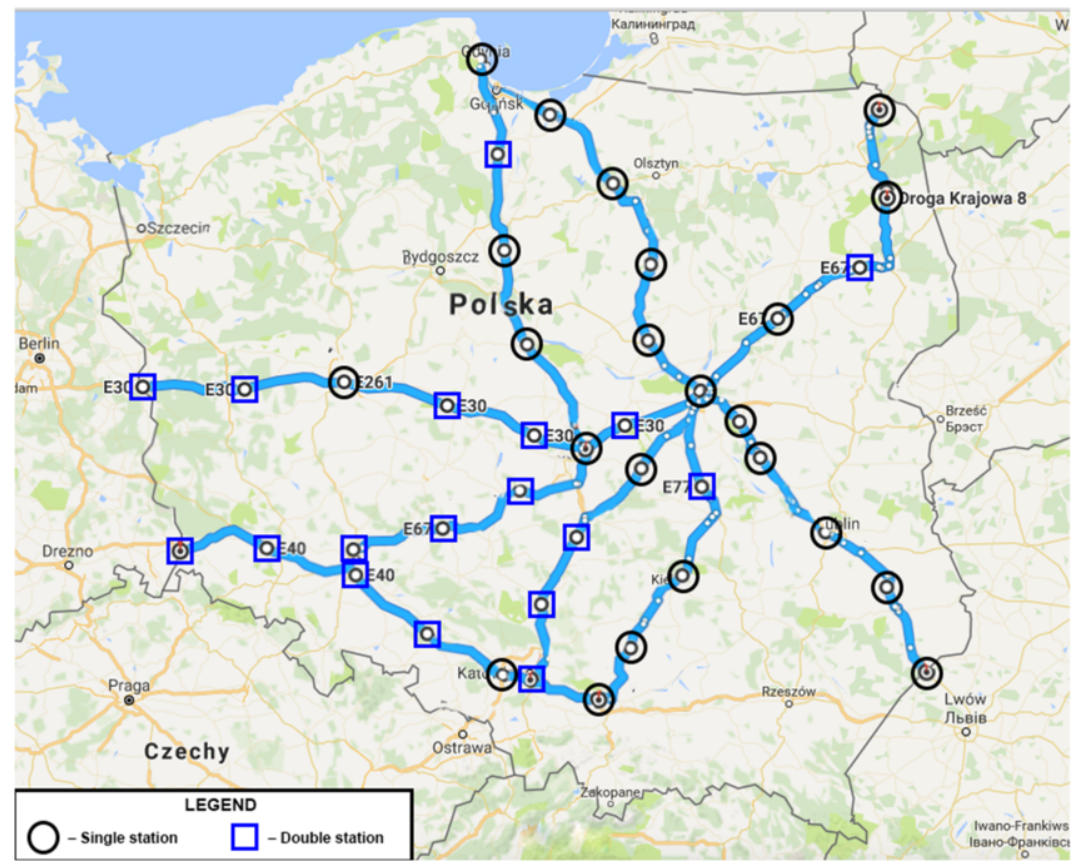

Figure 1. Proposal for fast charging station location. 
Considering such variables as the location and infrastructure of given road sections, it was possible to determine the number of fast charging points for electric vehicles. Their minimum number should oscillate at around 60 points (the number of stations was determined on the basis of the average range of electric vehicles - it was calculated based on the range of electric vehicles available on the market and the rejection of those with the largest range). With this infrastructure, it will be possible to use electric vehicles on roads belonging to the TERN transport routes and constituting road sections that will be heavily loaded in the perspective of 2020 , without worrying about the lack of places for charging vehicles.

Of course, the network of vehicle refuelling stations is much larger in the country. To optimize the costs of infrastructure construction, existing refuelling stations can be used during the construction of electric vehicle charging stations. This may prove to be a great help because of the 7807 petrol stations (as at the end of the third quarter of 2019). Similarly, given the analogy to cars with fossil fuels, whose range is usually over $500 \mathrm{~km}$, the density of refuelling stations is much greater than $500 \mathrm{~km}$, which results from a significantly larger number of cars powered by conventional fuel.4. The energy demand of an electric vehicle.

Based on own tests of an electric vehicle in real traffic conditions, it was possible to determine its average energy consumption. Then it was determined with the assumption of daily runs (about $60 \mathrm{~km}$ ), what would be the energy demand for one vehicle and energy costs related to it. Table 3 presents the energy consumption needed to recharge the batteries of the vehicle.

Table 3. Annual energy consumption needed to recharge the batteries of one vehicle.

\begin{tabular}{lc}
\hline \multicolumn{1}{c}{ Specification } & Parameter \\
\hline Daily mileage on business days & $60 \mathrm{~km}$ \\
\hline Daily mileage on Sundays and holidays & $60 \mathrm{~km}$ \\
\hline Annual mileage on business days & $15060 \mathrm{~km}$ \\
\hline Daily mileage on Sundays and holidays & $6840 \mathrm{~km}$ \\
\hline Total mileage & $21900 \mathrm{~km}$ \\
\hline Price 1 kWh for a household (G11 tariff) & $0,55 \mathrm{pln} / \mathrm{kWh}$ \\
\hline The cost of charging one vehicle a year & $2529,45 \mathrm{pln}$ \\
\hline Annual energy consumption needed to recharge the batteries of one vehicle & $4599 \mathrm{kWh}$ \\
\hline
\end{tabular}

Next, the results of the annual electricity consumption needed to charge the batteries of one electric vehicle were related to the assumed introduction in Poland of a million electric cars. On this basis, it was possible to determine the annual energy consumption needed to recharge the batteries of one million electric vehicles (Table 4). Then, the percentage of energy demand in the country will be estimated.

Energy consumption was calculated on the basis of own tests of electric vehicles in real road traffic conditions (RDE) with the use of the YOKOGAWA measuring device. After examining several electric vehicles available on the market, the test results were averaged and then used to calculate the average annual energy consumption of one vehicle and relate this to a million vehicles. The number of millions of vehicles is a reference number for Poland, which was specified by the government. 
Table 4. Energy demand for powering electric vehicles.

\begin{tabular}{lc}
\hline \multicolumn{1}{c}{ Specification } & Parameter \\
\hline Annual energy consumption needed to recharge the batteries of one electric vehicle & $4599 \mathrm{kWh}$ \\
\hline $\begin{array}{l}\text { Annual energy consumption needed to recharge the batteries of a million electric } \\
\text { vehicles }\end{array}$ & $4,599 \mathrm{TWh}$ \\
\hline A change in energy demand while supplying a million electric vehicles & $+2,7 \%$ \\
\hline
\end{tabular}

The calculations show that with one million vehicles the energy demand of the country will increase by $2.7 \%$. This is not a significant change with regard to the energy demand in the country in 2017 and 2018, which amounted to over $170 \mathrm{TWh}$. However, in 2018 the import of electricity to Poland amounted to $5.7 \mathrm{TWh}$, which is why charging electric cars would increase it almost twice [6]. It is best for financial reasons that this process takes place at night. The tariff adopted for calculation is a tariff applicable to households (G11) and amounts to $0.55 \mathrm{pln} / \mathrm{kWh}$. With this assumption, the annual costs related to the charging of an electric vehicle amount to 2529,45 pln. With regard to conventional vehicles, this is a significant difference at the moment.

\section{Hydrogen and hydrogen stations}

Area for practical use of hydrogen as a fuel carrier is transport, including in particular road transport. In recent years 2 motor companies (Hyundai, Toyota) have launched the serial production of fuel cell vehicles (FCEV) and others such as Volkswagen, Mercedes Benz, BMW, General Motors also produce such vehicles. The start of serial production by those companies depends on the availability of expanded hydrogen refuelling network of HRS (Hydrogen Refueling Stations). In 2016 there was the only c.a. 200 such stations available in the world. It is expected that by 2020 the number of HRS should come to approx. 1000 and by 2025 - to c.a. 3500 (Table 5).

Table 5. Number of public HRS worldwide in 2016 and their projected number in 2020-2025 [7].

\begin{tabular}{ccccc}
\hline Year & USA & Europe & Asia & Total \\
\hline 2016 & 60 & 100 & 103 & 263 \\
\hline 2020 & 130 & 520 & 340 & 990 \\
\hline 2025 & 600 & 2000 & 830 & 3430
\end{tabular}

This HRS in 2025 should provide service for approx. 2 million hydrogen vehicles. Currently approx. several thousand vehicles fuelled with hydrogen are used in the world, including more than 1000 in the US and 2000 in Japan and several hundred in Western Europe. Dynamic growth of fleets of hydrogen vehicles is planned - for example, China expects to have 50 thousand hydrogen vehicles in 2025 , to eventually exceed one million in 2030, whereas Japan will have a fleet of 40 thousand hydrogen vehicles in 2020 and almost 300 thousand in 2030. According to projections of $2014-$ the European fleet of hydrogen vehicles is expected to have 350 thousand vehicles in 2020 , the fleet in Japan - 100 thousand, in Korea - 50 thousand and the US -20 thousand [7]. 
Also, the fleet of hydrogen-fuelled buses is to be developed - in Europe it will have 1000 buses in 2020, while for instance in South Korea - almost 30 thousand buses by 2030 .

In Poland, there are practically no vehicles equipped with fuel cells (for that reason, at present, it is impossible to obtain a vehicle of this type for energy consumption tests, such research will be conducted at a later date). However, it was developed by Motor Transport Institute "Circumstances of the national plan for hydrogenization of road transport in Poland". In the first place taken into account were [1, 8]:

- already existing refuelling opportunities in the neighbouring countries,

- the expected future HRS locations in the Baltic countries,

- gradually increasing the area available for hydrogen-powered cars as a result of the subsequent location of new stations at distances up to $300 \mathrm{~km}$ from the existing or sequentially from the newly opened ones [1].

With this criteria, the order of preliminary proposals to build base HRS in Poland are as shown on figure 2: 1 - Poznan 2 - Warsaw, 3 - Bialystok, 4 - Szczecin, 5 - Lodz area, 6 - Tri-City area, 7 - Wroclaw, 8 - Katowice region, 9 - Cracow [1, 8].

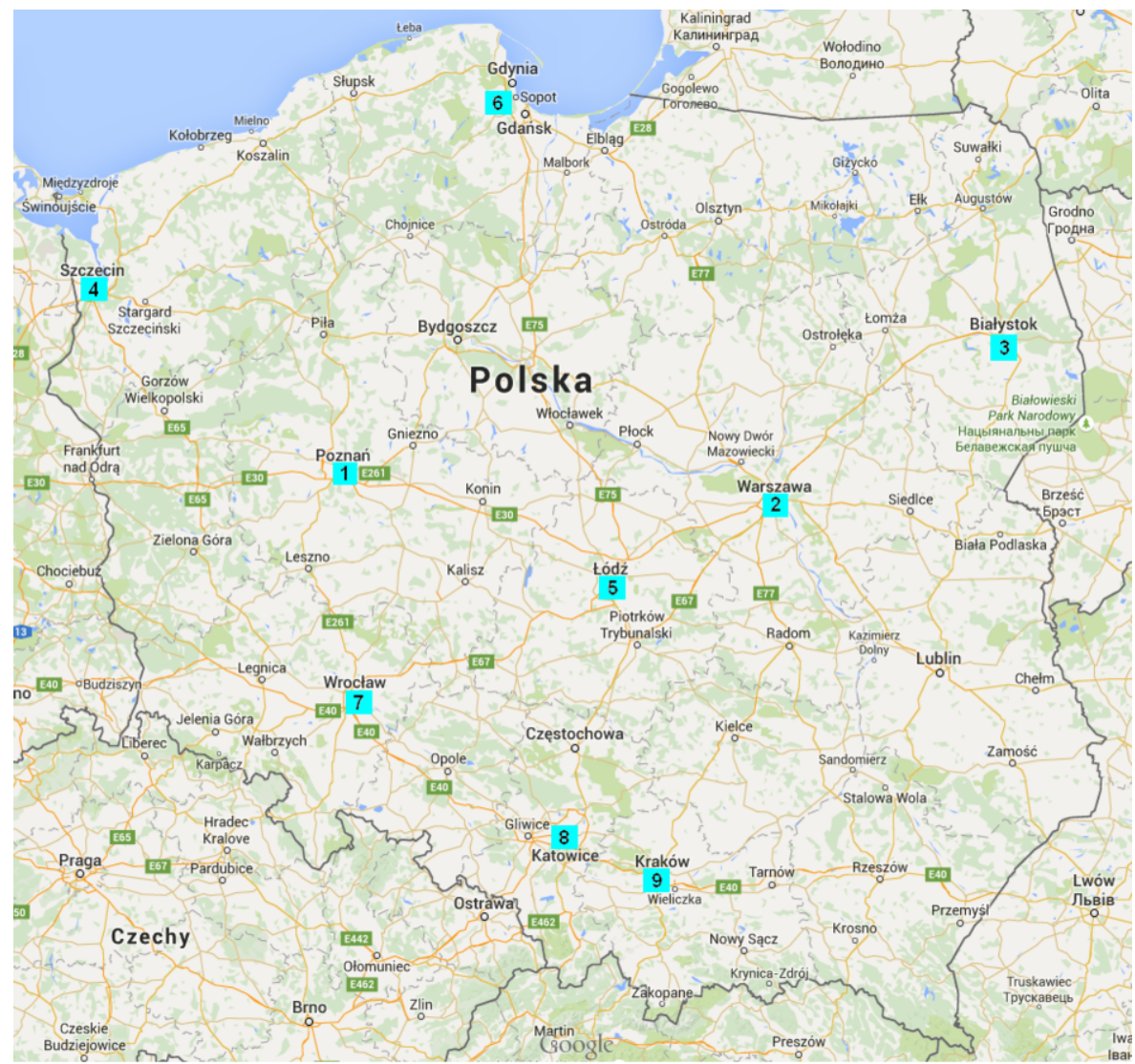

Figure 2. Map of Poland with marked sites of the proposed public hydrogen refuelling station locations [8]. 


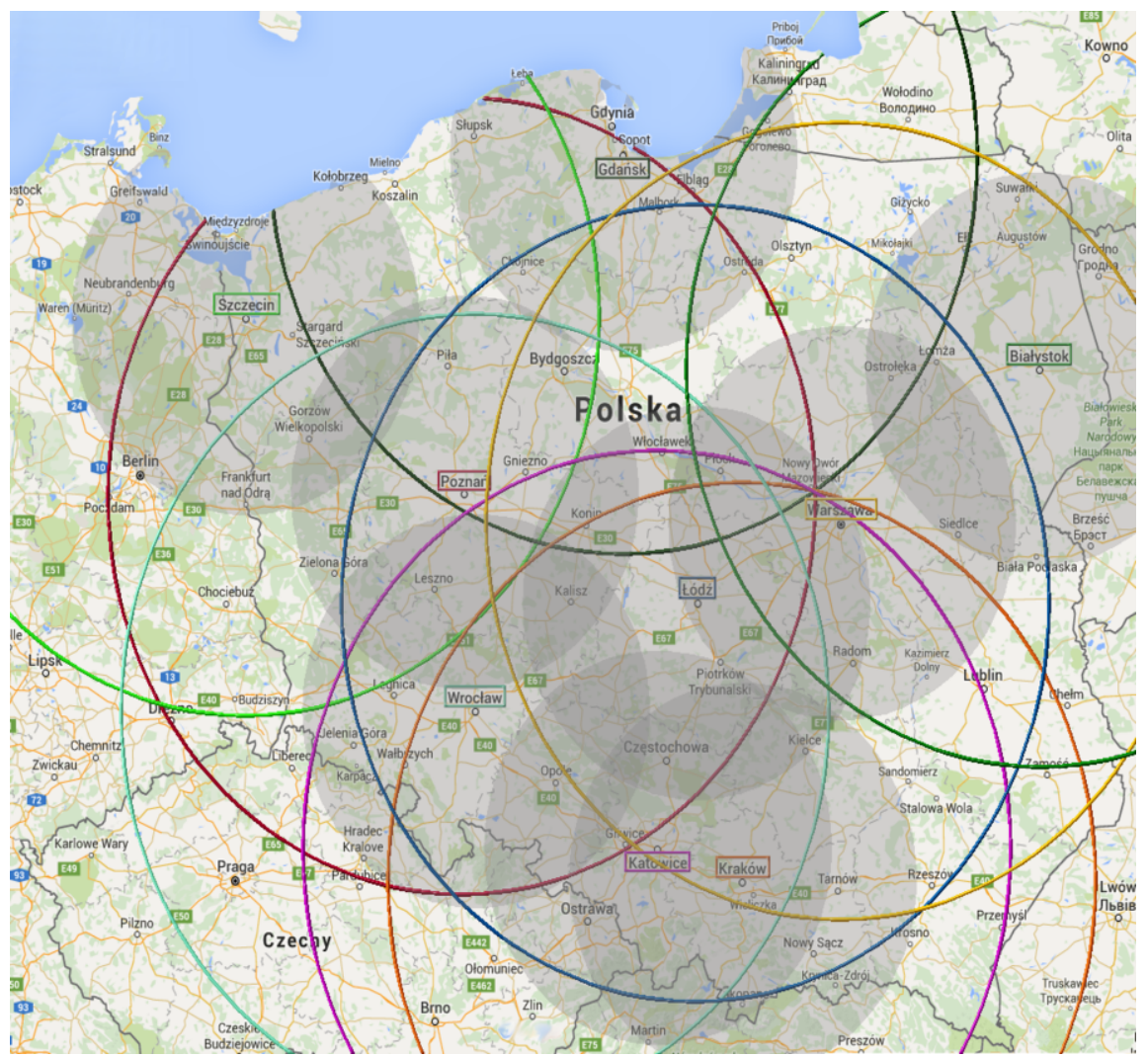

Figure 3. Penetration area of cars using fuel cells based on 9 hydrogen refuelling stations situated on the national TERN road network by 2030 [9] a) when driving in one direction (diameter of large circles - to approx. $600 \mathrm{~km}$ ), b) when driving there and back (diameter of small, shaded circles - to approx. $300 \mathrm{~km}$ ) [8]

Unfortunately, the estimates related to hydrogenation have not been met at the moment. The assumed plan to build 9-hydrogen refuelling points has not been implemented. It is assumed that in the coming years there is a high probability of establishing a station in Poznań and Warsaw.

\section{PESTEL Analysis of charging stations for electric vehicles at the TERN}

Political factors that can affect the development of fast-charging stations are very extensive. On the one hand, the EU wants Europe to be the first climate neutralcontinent, on the other, Poland wants to delay this process for economic reasons. A change in Poland's policy to generate electricity and a move away from fossil fuels towards renewable energy sources will be of great importance. However, environments related to the mining industry may make systemic changes difficult.

The soaring costs of living and running a business are not conducive to investment in new technologies, and electric cars should be considered as such. Also, rising electricity prices mean that this type of transport is not developing well in Poland. 
Social factors can support the process of transport electrification. The fashion of being an eco society, renting cars instead of buying, openness to new technologies, all this increases the interest in electric vehicles. In addition, the rapid development of technology strengthens interest, even by reducing production costs. However, only technical solutions that will shorten the charging time of an electric vehicle similar to the classic fuel method will attract new users. Such solutions are necessary to overcome the social resistance of people. Although legal factors can contribute to the development of fast-charging stations. Because the introduction of appropriate regulations and incentives will increase the sale of electric cars. In addition, inviters will be more interested in building new charging stations, especially since it is a simpler process than building a gas station. The lack of legal action will mean that nothing will change compared to the current state, and electric vehicles will be only curiosity and extravagance on Polish roads.

\section{Conclusions}

The development of the network of electric chargers and HRS in Poland along the roads belonging to TERN is a key aspect of the popularization of electric and hydrogen-powered cars. The most important aspects of system implementation are:

- Construction of nearly 60 fast-charging stations;

- The maximum distance between charging points is $110 \mathrm{~km}$;

- Increasing electricity supply by nearly $3 \%$ per year;

- Construction of HRS in at least 9 major urban centres in Poland;

- Changes in the law supporting users of electric and hydrogen vehicles.

\section{References}

[1] M. Gis, M. Bednarski, P. Orliński, Energy analysis of charging infrastructure for electric vehicles on the TEN-T road network, E3S Web of Conferences, 2019, 100, 00018.

[2] Krajowy bilans emisji SO2, NOX, CO, NH3, NMLZO, pyłów, metali ciężkich i TZO za lata 2015-2016 w układzie klasyfikacji SNAP. KOBiZE, styczeń 2018.

[3] NIK, Ochrona powietrza przed zanieczyszczeniami, 2018.

[4] W. Gis, J. Merkisz, The development status of electric (BEV) and hydrogen (FCEV) passenger cars park in the world and new research possibilities of these cars in real traffic conditions, PTNSS, 2019.

[5] W. Gis, E. Menes, J. Waśkiewicz, et al., Circumstances of the national plan or hydrogenization of road transport in Poland, Report prepared as part of the HIT-2-Corridors project, 2019.

[6] https://www.pse.pl/dane-systemowe/funkcjonowanie-rb/raporty-roczne-z-funkcjonowania-kse-zarok/raporty-za-rok-2018, Accessed June, 12020.

[7] N.N., H2 Mobility, USDOE, Hydrogen Europe, Air Liquid - cited from: How hydrogen empowers the energy transition, Hydrogen Council 2017, p. 9.

[8] N.N., Wdrożenie procedury dotyczacej przejazdu dla realizacji badań emisji zanieczyszczeń spalin (RDE). Praca statutowa 06/18/ITS/008. Instytut Transportu Samochodowego.

[9] M. Gis, Assessment of exhaust emissions from vehicles in real traffic conditions. International Conference on the Sustainable energy and environmental development, IOP Conference Series-Earth and Environmental Science, 2019, 214, 012035. 